\title{
Türk Futbolunda İthalat ve İhracatın Belirleyicileri ${ }^{1}$
} (Araştırma Makalesi)

\author{
Determinants of Import and Export in Turkish Football \\ Doi: 10.29023/alanyaakademik.873091
}

\author{
Adem TÜRKMEN \\ Dr. Öğr. Üyesi, Erzurum Teknik Üniversitesi, İktisadi ve İdari Bilimler Fakültesi, İktisat \\ Bölümü \\ adem.turkmen@erzurum.edu.tr \\ Orcid No: 0000-0002-1534-2332

\section{Hüseyin Devran ŞENOCAK} \\ Yüksek Lisans Öğrencisi, Erzurum Teknik Üniversitesi, Sosyal Bilimler Enstitüsü, İktisat \\ Anabilim Dall, \\ devransenocak@gmail.com. \\ Orcid No: 0000-0002-1871-1746
}

Bu makaleye atıfta bulunmak için: Türkmen, A. \& Şenocak, H. D. (2021). "Türk Futbolunda İthalat ve İhracatın Belirleyicileri”, Alanya Akademik Bakış, 5(3), Sayfa No.1393-1410.

\section{Anahtar kelimeler: \\ Dış Ticaret, Futbol \\ Ekonomisi, İhracat, \\ Ithalat.}

Makale Geliş Tarihi:

02.02.2021

Kabul Tarihi:

07.07.2021

Keywords:

Football Economy,

Foreign Trade,

Export, Import.

\begin{abstract}
ÖZET
Küreselleşmeyle birlikte ekonomik yapı kazanarak büyük bir endüstri halini alan futbolda, uluslararası futbolcu transferleri önemli seviyelere ulaşmıştır. Bu makalenin amaci; uluslararası futbolcu transferleri vasitastyla ortaya çıkan futbolda dış ticaretin belirleyicilerini tespit etmek ve bu belirleyicilerin etkilerini değerlendirmektir. Bu amaçla, Türkiye Süper Lig'in futbolcu ihracat ve ithalatı bağıml değişkenler olarak ele alınarak zaman serisi analizleri uygulanmıştır. Zaman serisi analizlerin sonucunda; Türkiye GSYH, Avrupa Birliği GSYH, reel efektif döviz kuru, Finansal Fair Play kurallarl, uygulanan yabancı futbolcu kuralı, Türkiye A Milli Futbol Takımı'nın uluslararası turnuvalara katılma başarısı göstermesi ve bir önceki dönemin futbolcu ithalat miktarı Türkiye Süper Ligi için futboldaki dış ticaretinin belirleyicileri olarak tespit edilmiştir.
\end{abstract}

\begin{abstract}
In football, which has become a major industry by gaining an economic structure with globalization, international football player transfers have reached significant levels. The aim of this article is to determine the determinants of foreign trade in football that emerges through international player transfers and to evaluate the effects of these determinants. To this end, footballer exports and imports of Turkey Super League have been adopted as the dependent variable and time series analysis has been applied. As a result of time series analysis, the following variables were determined as the determinants of foreign trade in football for the Turkish Super League; Turkey GDP, European Union GDP, real effective exchange rate, Financial Fair Play rules, applied foreign football player rule, Turkish National Football
\end{abstract}

\footnotetext{
${ }^{1}$ Bu makale Futbolda Dış Ticaretin Belirleyicileri: Türkiye Örneği adlı yüksek lisans tezinden uyarlanmıştır.
} 
Team's success in participating in international tournaments and football player import amount of the previous period.

\section{GİRIŞ}

Futbol; 1866 yılında İngiltere'de gerçekleşen ilk resmi müsabakadan beri sürekli olarak bilinilirliğini artırarak, milyonlarca insanı peşinden sürükleyen ve eğlence, medya, bahis, tekstil, turizm, ulaşım vb. sektörleri içerisinde bulunduran büyük bir endüstri haline gelmiştir (Orçun ve Demirtaş, 2015: 114). Futbol endüstrisinin temelini oluşturmakta olan futbol kulüpleri, belirli koşullar içerisinde ve belirli piyasa kurallarına uygun hareket etmek koşuluyla, maksimum kazanç ve fayda elde etmek isterler. Üretim, tüketim, dağılım ve gelişimin aşamalarını dikkate alarak inceleyen ve belirlenen bağlantıları tanımlayan futbol ekonomisi, iktisadi araştırma alanlarının farklı bir faaliyet alanı olma özelliği taşımaktadır (Güreş, 2006: 14). Futbol kulüplerinin firmalara benzetildiği bu ekonomide futbol müsabakaları çıktı (ürün) olarak kabul edilmektedir. Futbolcular, üretim faktörlerinin emek bölümünü; stadyum ve tesisler ise sermaye bölümünü oluşturmaktadır. Futbol kulüpleri ise bu emek ve sermayeyi bir araya getirerek, satılabilir bir ürün ve hizmet olan futbol karşılaşmalarını üretmektedir (Yiğit, 2018: 5).

1995 yılında alınan Bosman kararlarının ardından kulübü ile kontratları sona eren futbolculara serbest transfer hakkı tanınmasıyla, futbolda emek ve sermeyenin serbest dolaşımı mümkün hale gelmiştir (Akşar, 2005: 12). Bu durum futbolcu ithalat ve ihracatlarında artışları beraberinde getirerek, futboldaki dış ticaret hacminin önemli seviyelere çıkmasını sağlamıştır. Böylece futbolda dış ticaret işlemlerinin analiz edilmesinin gerekliliği ortaya çıkmıştır.

Bu çalışmada Türkiye Süper Lig kulüplerinin futbolcu transfer işlemlerinden kaynaklanan futbolcu ithalat ve ihracatındaki değişimlerin analiz edilmesiyle, futbolda dış ticaretin belirleyicileri tespit edilerek, bu belirleyicilerin Türkiye'nin futboldaki dış ticareti üzerindeki etkileri değerlendirilmiştir.

\section{FUTBOL EKONOMISİ}

Futbolun temelleri 19. yüzyılın başlarında futbolun beşiği olarak nitelendirilen İngiltere'nin devlet üniversiteleri ve yüksekokullarında atılmıştır. İlk futbol müsabakası 1848'de Cambridge Üniversitesi'nde gerçekleştirilmiştir. Bunun akabinde ise 1863 yılında İngiltere Futbol Federasyonu (FA) kurulmuştur (Aydın, 2008: 3). FA'nın kurulmasının ardından 1871'e kadar futbol amatör olarak oynanmaya devam etmiştir. 1871 yılında Federasyon Kupası maçlarının başlamasıyla beraber maç bileti satışlarından gelir elde edilmesi, futbolda profesyonel yapıya geçilerek ücret karşılığı oyuncu oynatabilmenin en önemli nedenlerinden biri olmuştur (Buraimo, vd., 2006: 29). Futbolculara profesyonel olarak ilk ödemelerin yapılması, 1876'da Britanya'daki futbol müsabakalarının ardından gerçekleşmiştir. Profesyonellik ilkesi ise 1885 yılında FA tarafından kabul edilmiştir. Bu durum ligin oluşumunun en önemli sebebidir (Williams ve Neatrour, 2002: 1). Futbol kulüplerinin futbolcu ödemelerini düzenli olarak yerine getirmesi ve futbolcuların da söz konusu ödemeleri hak etmeleri için müsabakalarının gerçekleşebileceği düzenli bir sisteme ihtiyaç duyulmuştur. Aston Villa Kulübü Başkanı 1888 'de belirli bir oyun düzenine sahip olan bir lig kurulmasını teklif etmiştir. Bu teklif üzerine dünyadaki ilk profesyonel lig, 12 futbol kulübünün katılımıyla kurulmuştur (Akşar ve Kutlu, 2006: 39). 
Bu gelişmelerden sonra transfer kısıtlamaları ve maksimum ücret uygulamaları uzun bir dönem futbol ekonomisine yön vermiştir (Çakmak, 2019: 19). 1885'te uygulanmaya başlayan transfer kısıtlamalarında; futbolcular, kulüplerinin izni olmadan başka bir kulübe transfer gerçekleştirememekteydi. Futbol kulüpleri, futbolcularının izni olmadan, her bir sezon için FA'ya futbolcularının kontratlarını tescil ettirmekteydi. Söz konusu bu uygulama, İngiltere'nin Newcastle United kulübünün transferine engel olduğu futbolcusu George Eastham'in başvurusunun sonucunda Yüksek Mahkeme'nin kararıyla 1963 yılında iptal edilmiştir. Karar neticesinde futbolcuların kulüpleriyle sözleşmelerini uzatmaması durumunda farklı bir kulübe transfer yapmalarına olanak tanınmasına rağmen futbolcuların kontratlarının bittiği takımlardan onay almaları koşulu şart koşulmuştur. Bu durum, futbolcuların kulüplerle pazarlık güçlerini azaltmış ve transfer fiyatlarının yükselmesini engellemiştir (Dobson ve Goddart, 2001: 181). Maksimum ücret uygulamasında ise kulüpler tarafindan futbolcularına FA'nın belirlemiş olduğu ücretin üzerinde ödeme yapılamamaktadır. 1901 yılında haftalık 4 sterlin olarak belirlenen maksimum ücret, 1958 yılında haftalık 20 Sterlin'e çıkarılmıştır. Maksimum ücret uygulamasının gerçekleştirildiği dönemde belirlenen miktardan fazla ödeme yapan kulüpler cezalandırılmıştır. 1960'ta futbolcuların daha fazla ücret istemeleri ve grev tehdidinde bulunmalarının ardından 1961'de FA maksimum ücret uygulamalarına son vermiştir. Maksimum ücret uygulamasının iptaliyle birlikte futbolcu ücretlerinde önemli miktarda artışlar yaşanmıştır (Çakmak, 2019: 28).

1960’tan sonraki dönemde yayıncıllk sektörü ve sponsorların futbol ile ilişki kurması, özellikle de 1990 sonrasındaki gelişmeler çok fazla finans kaynağı bulunmayan ve giderlerinin önemli kısmını maç günü gelirlerinden karşılayan kulüplerin gelir yapılarında büyük değişimlere neden olmuştur. Bu değişimlerin en temel sebeplerinden birisi Bosman Kararları'dır (Horasan, 2007: 26). Alınan karar kulüplerin transfer sistemlerini değiştirmiş ve futbolda endüstrileşme adına önemli bir eşik aşılmıştır (Dobson ve Goddart, 2001: 181).

\section{FUTBOLDA DIŞ TICARET}

Mal, hizmet, sermaye ve telif haklarının ülkeler tarafından karşılıklı olarak değişimi şeklinde gerçekleşen ticaret, dış ticaret olarak adlandırılmaktadır (Mete, 2013: 9). En temel anlamıyla ele alındığında dış ticaret, ithalat ve ihracat faaliyetlerinin toplamıdır (Gültekin ve Savcı, 2008: 1). Dış ticaret geniş anlamı ile ele alındığında ise mal ticaretine ek olarak, dış ticaret işlemleri; uluslararası hizmet ticareti, uluslararası yatırım ile gelir ve giderleri de kapsamaktadır (Utkulu ve Aydemir, 2013: 3-4). Bu açıklamalar 1şığında futbolda dış ticaret kavramına bakıldığı zaman; farklı ülkelerin futbol kulüpleri arasında gerçekleşen futbolcu transfer işlemleri ve naklen yayın haklarının başka ülkelere satılması futbolda dış ticaret işlemlerine örnek olarak verilebilecektir. Futbolun küreselleşmesi ve endüstri halini almasıyla birlikte dünya genelinde popülerliği ve izlenilirliği artmıştır. $\mathrm{Bu}$ artışlar neticesinde ligler naklen yayın haklarının satışını gerçekleştirerek naklen yayın geliri elde ederken, kulüpler ise lisanslı ürünlerinin dünya genelinde pazarlama ve satış çalışmalarını yürüterek ticari gelir elde etmektedirler. Futbolda dış ticaretin temelini futbolcu ithalatı ve ihracatı oluşturmaktadır. Futbol kulüplerinin sportif başarı, taraftarlarının beklentilerinin karşılanması ve gelirlerinde artış sağlamak için yurt dışından yaptıkları transferler futbolcu ithalatını oluştururken, futbolcuların kulüpleri tarafından yurt dışına satışlarının gerçekleşmesi ise futbolcu ihracatını oluşturmaktadır.

Ekonomik büyümenin, üretim faktörleri stokundaki artışlar ve teknolojik gelişmeler olmak üzere 2 temel kaynağı bulunmaktadır. Ülkedeki üretim, tüketim ve dolayısıyla aralarındaki farkın yansıtılmasını sağlayan ekonomik büyüme dış ticaret üzerinde de etki oluşturmaktadır. 
Diş ticaret ve büyüme arasında çift yönlü ilişki mevcuttur (Seyidoğlu, 2015: 119-142). Futbolda da dış ticaret ile büyüme arasında aynı yönlü ilişki bulunduğu, artan dış ticaretle birlikte büyümenin de gerçekleştiği görülmektedir. Dış ticaret faaliyetleri futbolda komple bir ekonomik gelişim oluşturmaktadır. Futbol ekonomisine yön veren büyük ligler, yaptıkları transferler ve bu sayede kazandıkları sponsorluk gelirleri sayesinde finansal sürdürülebilirliklerini sağlarken beraberinde daha az ekonomik güce sahip olan liglerin de büyüme ve gelişimine etki etmektedirler. Daha az ekonomik güce sahip olan ligler, daha fazla ekonomik güce sahip olan liglerin analizlerini gerçekleştirerek, ekonomik yapılarını geliştirmekte ve güçlendirmektedir.

Dış ticaretin ülkeler için büyük avantajlar sağladığı bilinmektedir. Ülkeler kendi vatandaşlarının taleplerinin karşıladıktan sonra ellerinde kalan fazla ürünleri ihraç edebilmek için gerekli olan dış pazarı belirleyip gelir elde etme şansını yakalamaktadır. Ülkeler bu ürünlerin pazarlamasını yaparken aynı zamanda diğer ülkelerle de rekabet etmek zorundadırlar. Ülkeler arasında oluşan bu rekabet, üretim etkinliğinde artışa ve teknolojide gelişmelere neden olmaktadır. Bunların sonucunda ise nitelikli, iyi yetişmiş, uzman, kalifiye kişilerin yetişmesi sağlanmaktadır. Dış ticaret faaliyetleri sayesinde ülkeler birbirleriyle yakınlaşmaya başlarken, farklı ülkelerde bulunan tüketiciler diğerlerinin davranışları hakkında bilgi sahibi olma firsatı yakalarlar (Mete, 2013: 17). Dış ticaret işlemleri, futbol endüstrisinde de önemli avantajlar sağlamaktadır. Futbolcuların ve paranın serbest dolaşımını sağlayan futbolda dış ticaret, ülke futbolunun özellikle ekonomik anlamdaki gelişimi için büyük bir önem teşkil etmektedir. Futbolun dünya genelindeki tanıtım gücü sayesinde, futbol kulüpleri pek çok uluslararası şirket ile reklam ve sponsorluk anlaşmaları yaparak büyük ekonomik kazanımlar elde etmektedir. Uluslararası transfer işlemleriyle birlikte medyanın ilgi odağı olan futbol takip edilirliğini ve seyirci sayısını artırmaktadır. Ayrıca uluslararası olarak gerçekleșen büyük turnuvalar sayesinde de futbol kulüpleri büyük gelir elde etmektedirler. Bu durum Türkiye futbol kulüpleri açısından değerlendirildiğinde; UEFA'nın en önemli organizasyonlarından biri olan Şampiyonlar Ligi'ne katılmayı başaran Türk kulüpleri, elde ettikleri döviz geliriyle birlikte ekonomik olarak büyük bir girdi sağlamakta ve finansal olarak önemli ölçüde rahatlamaktadırlar.

Dış ticaret ülkeler için bazı dezavantajlı durumlar da ortaya çıkarabilmektedir. İthalatın aşırı yükselmesi, ülke içerisinde üretimde azalmaya neden olmaktadır. İstihdamda azalmaya neden olan üretim kaybı işsizlikte artış oluşturmaktadır. Bu olumsuz etkiler ekonomide daralma meydana getirerek ülkeler üzerinde olumsuz etki oluşturmaktadır (Ketboğa, 2020: 10). Dış ticaretin futbol ekonomisinde oluşturduğu dezavantajlar incelendiğinde ise; özellikle ulusal parasının değeri daha düşük olan ülkelerde bazı olumsuz durumlara yol açabilmektedir. Artan yabancı futbolcu transferleri neticesinde döviz cinsinden borçlanılması, futbol kulüplerinin gelir-gider dengelerini sağlamalarını zorlaştırmaktadır. Finansal istikrarını sağlayamayan futbol kulüpleri, futbolculara ve bonservis ödemesi gerçekleştirmesi gereken futbol kulüplerine, ödemeleri geciktirebilmekte veya hiç yapamamaktadır. Gelirlerinin büyük bir kısmı yerel para birimi cinsinden olan futbol kulüpleri, döviz cinsinden büyük borçlanmalara gittiklerinde ciddi ekonomik krizler yaşayabilmekte ve kulüp varlıklarını sonlandırma riski ile karşı karşıya kalmaktadırlar. Şüphesiz ki bu husustan korunmakta en önemli olay futbol kulüplerinin alanlarında uzman profesyonel kişiler tarafından yönetilmesi ve gelir-gider dengesinin sağlanmasıdır. 
Dış ticarette rekabet avantajı sağlamada önemli bir unsur olan ölçek ekonomileri; ekonomik faaliyet gösteren bir birimde, üretim kapasitesi ölçeği büyüdükçe üretim artış oranının maliyetlerdeki artış oranından daha fazla olması sonucunu oluşturan faktörlerdir. Ölçek ekonomileri sonucunda, uzun dönem ortalama maliyetler azalan bir seyir izlemektedir (Türko, 2013: 47). Ölçek ekonomisi barındıran ürünler, çok sayıdaki küçük üretici şirket yerine az sayıdaki büyük şirket tarafından üretilmektedir. Bu durum küçük ölçekli şirketlerin, büyük ölçeğe sahip şirketler ile rekabet etmesini güçleştirerek uluslararası ticarette ölçek ekonomilerinin önemini artırmaktadır. Ölçek ekonomilerinin büyük şirketlere bu avantajları oluşturup oluşturmadığı, bu ekonomilerin içsel ya da dışsal nitelikte olmasına bağlıdır. İçsel ölçek ekonomileri, şirketlerin iç dinamiklerindeki gelişmeler sonucunda değerinin artması olarak tanımlanabilir. Dışsal ölçek ekonomileri ise şirketlerin içinde bulunduğu endüstriden kaynaklı iyileşmelerdir. İçsel ve dışsal ölçek ekonomilerinin yanı sıra şirketleri etkileyen bir diğer faktör ise dişsallıklardır. Bir üretim veya tüketim olayının 3. kişilerde olumlu ya da olumsuz etki oluşturmasına dışsallık adı verilmektedir (Seyidoğlu, 2015: 108). Futbol özelinde ölçek ekonomileri düşünüldüğünde; futbol kulüpleri şirketleri, ligler ve uluslararası organizasyonlar ise endüstriyi temsil edebilecektir. Futbol kulüplerinin gerçekleştirdikleri altyapı yatırımları ile genç futbolcular yetiştirerek futbola kazandırmaları, yürüttükleri reklam ve pazarlama faaliyetleriyle kulüp bilinilirliğini artırmaları ve kulüp mali yapılarında istikrarı sağlayarak bankalardaki kredibilitelerini yükseltmeleri içsel ölçek ekonomileri olarak düşünülebilir. Diğer taraftan liglerin yayın haklarının daha pahalıya satılması ve futbol kulüplerinin uluslararası turnuvalardan daha çok gelir elde etmeleriyse dışsal ölçek ekonomileri olarak nitelendirilebilir. Futbolculardan alınan vergi miktarları ve üniversitelerde ilgili bölümlerde uzman kişilerin yetiştiriliyor olması ise dışsallığa verilebilecek diğer örneklerdir.

\section{LITERATÜR ARAŞTIRMASI}

Futbol ekonomisi alanındaki çalışmalar incelendiğinde, genellikle FFP'nin uyum ve etkinliği ile futbolda rekabete etkisi üzerinde durulduğu görülmektedir. Peeters ve Szymanski (2012), Flanagan (2013) ve Schubert vd., (2016) çalışmalarında bu konu üzerinde durmuş ve FFP'nin gelir-gider dengesini sağlamada etkili olduğu ve rekabet gücünü artırdığı sonuçlarına varmışlardır. Ricci vd., (2013), Dimitropoulos ve Koumanakos (2015), Leitao ve Baptista (2019) entelektüel sermaye yapıları ve etkileri üzerine gerçekleştirdikleri çalışmalarda, müşteri sermayesinin etkinliğini futbol kulüplerinin yabancı müşterilerle ilişkilerinin arttırdığını, entelektüel sermaye ve kârlılık arasında pozitif bir ilişki olduğunu ve futbolculardaki değer artışı ile kulüplerin marka değerlerinin arttığını tespit etmişlerdir. Futboldaki gelir kaynaklarını Salehnia ve Nasrabadi (2019) girişimci bir yaklaşımın futbol kulüplerinin gelirlerine etkisi bakımından incelemiş ve bu durumun gelirler üzerinde etkili olduğu sonucuna ulaşmışlardır. Sanchez vd., (2019) ise bu konuyu gelirlerdeki artışların giderlerin üzerindeki etkileri ve kulüp mali yapısı kontrolü bakımından ele alarak, gelirlerle birlikte giderlerinde arttığı sonucuna varmışlar ve bu durumun kontrol altında tutulması gerektiğini belirtmişlerdir.

Türkiye'de gerçekleştirilen futbol ekonomisi çalışmalarına genel olarak bakıldığında ise; Orçun ve Demirtaş (2015), Çakmak (2018) ve Şenol (2018) taraftarlık olgusunu temel alan çalışmalarında, taraftar kulüp ilişkileri, taraftar sayısındaki değişmelerin sebepleri ve futbolda tüketici konumunda olan taraftarların tercihleri hakkında bilgiler vermiştir. Demir (2019) profesyonel futbolcuların piyasa değerleri ve futbolcular için ödenen transfer ücreti arasındaki değişkenliğe sebep olan etkenleri inceleyerek, transfer ücretinin belirlenmesinde 4 ana temanın varlığından söz etmiştir. Çakmak (2019) ise Süper Lig'in gelir bakımından Avrupa'nın beş 
büyük liginden geride olduğunu belirtmiştir. Sunay (2004), Akkaya (2008), Talimciler (2008) ve Ekmekçi-Dağlı vd., (2013) küreselleşmeyle birlikte futboldaki şirketleşmeyi ele alarak futbolun yapısında oluşturduğu etkiler üzerinde durmuşlardır. Elbir (2018) markalaşmanın Türkiye ve Avrupa'daki profesyonel futbol kulüplerinin ekonomik yapıları üzerinde oluşturduğu olumlu etki üzerinde dururken, Ay (2016) ise futbolun bölgesel kalkınma üzerindeki pozitif etkisini ele almıştır. Devecioğlu (2004), Uluyol (2014), Karadeniz vd., (2014), Güngör (2014) ve Zeren (2014) çalışmalarında, sportif başarı ile finansal performans arasında doğru yönlü bir ilişkinin bulunduğu ve bu durumun hisse senedi fiyatları üzerinde de etkileri olduğunu tespit etmişlerdir. Saban ve Demirci (2016), Özevin (2017), Sevim ve Bülbül (2017), Akalın (2018) ve Terci (2019) ise FFP kriterlerini ele aldıkları çalışmalarında, Türk futbol kulüplerinin bu kurallara uyum gösteremediği ve mali dengeyi sağlayabilmek için söz konusu kurallara uyum sağlanması gerekliliği üzerinde durmuşlardır. Soygüden (2016) ve Keleş (2019) sportif başarıların kulüplerin gelirlerinde hızlı bir şekilde artış sağladığını gözlemlemişlerdir. Fişne ve Bardakçı (2019) ise yabancı futbolcu sınırlamasına yönelik görüşleri incelemiş ve katılımcıların yarısına yakınının Türk futbolundaki yabancı futbolcu sayısının sınırlandırılmasına karşı çıktığını tespit etmişlerdir.

\section{VERİ SETİ VE YÖNTEM}

Türkiye'nin futboldaki ihracat ve ithalatının belirleyicilerinin tespit edilmesi amacıyla gerçekleştirilen zaman serisi analizlerinde, 2001-2002 futbol sezonu yaz transfer dönemi ile 2019-2020 futbol sezonu yaz transfer dönemi aralığında bulunan, yaz ve kış transfer dönemlerinden oluşan toplam 37 transfer dönemi ele alınmıştır. 2001-2002 futbol sezonu yaz transfer döneminin başlangıç olarak seçilmesinin sebebi futbolun ekonomik büyümesinin 2000'li yıllardan sonra gerçekleşmesi ve bu dönem öncesinde ulaşılabilen bağımlı değişken verilerinin analize katılamamasıdır. Analizlerde Türkiye Süper Lig'in toplam verileri kullanılmıştır. Türkiye Süper Lig'in futbolcu ihracat ve ithalatı bağımlı değişkenlerinin, bağımsız değişkenler olarak ele alınan Türkiye GSYH, Avrupa Birliği GSYH, reel efektif döviz kuru, uygulanan yabancı futbolcu kuralı, Türkiye A Milli Futbol Takımı'nın uluslararası turnuvalara katılma başarısı göstermesi ve UEFA FFP uygulamalarının yürürlüğe girmesi değişkenleriyle ilişkileri incelenmiştir.

Çalışmada futbol ekonomisine ve dış ticaretin belirleyicilerine yönelik ulusal ve uluslararası veriler kullanılmıştır. Zaman serisi analizlerinde kullanılan söz konusu verilerin; açıklamaları, analizlerde kullanılan kısaltmaları ve veri kaynakları Tablo 1'de verilmiştir.

Tablo 1. Zaman Serisi Analizlerinde Kullanılan Değişkenler

\begin{tabular}{|c|c|l|c|}
\hline VERININ ADI & KISALTMALAR & \multicolumn{1}{|c|}{ VERININ AÇIKLAMASI } & VERI KAYNAĞI \\
\hline $\begin{array}{c}\text { Futbolcu } \\
\text { İhracat } \\
\text { Rakamları }\end{array}$ & LX & $\begin{array}{l}\text { Türkiye Süper Lig kulüplerinin futbolcu satış ve kiralama } \\
\text { işlemlerinden kaynaklanan ihracat rakamları (Milyon Euro), } \\
\text { (Logaritmik) }\end{array}$ & Transfermarkt \\
\hline $\begin{array}{c}\text { Futbolcu İthalat } \\
\text { Rakamları }\end{array}$ & LM & $\begin{array}{l}\text { Türkiye Süper Lig kulüplerinin futbolcu alış ve kiralama } \\
\text { işlemlerinden kaynaklanan ithalat rakamları (Milyon Euro), } \\
\text { (Logaritmik) }\end{array}$ & Transfermarkt \\
\hline Türkiye GSYH & LY & $\begin{array}{l}2010 \text { Baz Y1 Düzeltilmemiş Veriler (Milyon Euro), } \\
\text { (Logaritmik), Yaz transfer dönemi için ilgili yıldaki dönemin } \\
\text { 3. çeyrek ve 4. çeyrek verilerinin toplamı, kış transfer dönemi } \\
\text { için ise ilgili yıldaki dönemin 1. çeyrek ve 2. çeyrek verilerinin } \\
\text { toplamı kullanılmıstır. }\end{array}$ & Eurostat \\
\hline
\end{tabular}




\begin{tabular}{|c|c|c|c|}
\hline $\begin{array}{c}\text { Avrupa Birliği } \\
\text { GSYH }\end{array}$ & LEU & $\begin{array}{l}2010 \text { Baz Yıl Düzeltilmemiş Veriler (Milyon Euro), } \\
\text { (Logaritmik), Yaz transfer dönemi için ilgili yıldaki dönemin } \\
\text { 3. çeyrek ve 4. çeyrek verilerinin toplamı, kış transfer dönemi } \\
\text { için ise ilgili yıldaki dönemin 1. çeyrek ve 2. çeyrek verilerinin } \\
\text { toplamı kullanılmışıtır. }\end{array}$ & Eurostat \\
\hline $\begin{array}{l}\text { Reel Efektif } \\
\text { Döviz Kuru }\end{array}$ & LE & $\begin{array}{l}\text { TÜFE Bazlı }(2003=100), 6 \text { aylık veriler esas alınarak } \\
\text { hazırlanmıştır. Yaz transfer dönemi için ilgili yıldaki } 2 \text {. dönem } \\
\text { verileri, kış transfer dönemi için ise ilgili yıldaki } 1 \text {. dönem } \\
\text { verileri kullanılmıştır. (Logaritmik) }\end{array}$ & TCMB EVDS \\
\hline $\begin{array}{c}\text { Uygulanan } \\
\text { Yabanc1 } \\
\text { Futbolcu Kuralı }\end{array}$ & RST & $\begin{array}{l}\text { TFF tarafindan 2015-2016 futbol sezonunda yürürlüğe } \\
\text { koyulan ve hala uygulanmakta olan yabanc1 futbolcu } \\
\text { kuralından önceki ve sonraki dönem karşılaştırması } \\
\text { yapıllmıştır. }\end{array}$ & TFF \\
\hline $\begin{array}{l}\text { Türkiye A Milli } \\
\text { Futbol } \\
\text { Takımı'nın } \\
\text { Uluslararası } \\
\text { Turnuvalara } \\
\text { Katılma } \\
\text { Başarısı } \\
\text { Göstermesi }\end{array}$ & TOUR & $\begin{array}{l}\text { Türkiye A Milli Futbol Takımı'nın Dünya Kupası veya } \\
\text { Avrupa Futbol Şampiyonası turnuvalarından herhangi birine } \\
\text { katılamadığı turnuvadan bir sonraki turnuvaya kadar olan } \\
\text { dönemler ile Türkiye A Milli Futbol Takımı'nın Dünya Kupası } \\
\text { veya Avrupa Futbol Şampiyonası turnuvalarından herhangi } \\
\text { birine katıldığı turnuvadan bir sonraki turnuvaya kadar olan } \\
\text { dönemler karşılaştırılmıştır. }\end{array}$ & Transfermarkt \\
\hline $\begin{array}{l}\text { UEFA FFP } \\
\text { Uygulamalarını } \\
\text { n Yürürlüğe } \\
\text { Girmesi }\end{array}$ & FFP & $\begin{array}{l}\text { UEFA tarafından Finansal Fair Play kurallarının } \\
\text { açıklanmasından önceki ve sonraki dönem karşılaştırılmıştır. } \\
\text { UEFA tarafından FFP kurallarının açıklandığı yıl olan } 2010 \\
\text { yılı esas alınmıştır. }\end{array}$ & UEFA \\
\hline
\end{tabular}

\section{ANALIZ}

Analizlerde bağımlı değişkenler olan ihracat ve ithalat için, Türkiye Süper Lig'de mücadele eden futbol kulüplerinin futbolcu transfer rakamları, uluslararası kabul gören "Transfermarkt" internet sitesinden elde edilmiş ve Türkiye Süper Lig futbol kulüplerinin verileri tek bir havuzmuş gibi ele alınarak, belirlenen toplam ihracat ve ithalat rakamları kullanılmıştır. Türkiye'nin 2001-2019 yılları arasında futboldaki dış ticaretinin belirleyicilerini tespit etmek amacıyla uygulanacak analizlerdeki model seçiminin belirlenmesi için ilk olarak değişkenlere birim kök testleri uygulanmıştır. Elde edilen analiz sonuçları incelenerek testin devamı için karar vermek amacıyla değerlendirmeler yapılmıştır. Tablo 2'de yer alan birim kök testleri incelendiğinde, analizlerde yer alan LM, LX ve LY değişkenlerinin PP test sonuçlarına göre $\% 1$ önem seviyesinde düzeyde durağan oldukları ve Şekil 1'deki grafiklerle incelendikleri zaman bu üç değişkenin trend içeren bir durağanlığa sahip olduğu görülmektedir. LEU değişkenin \%10 önem seviyesinde trend içeren düzeyde durağanlığa sahip olduğu gözlemlenirken, LE değişkeninin 1. farkta durağan olduğu görülmektedir.

Tablo 2. İthalat ve İhracatın Belirleyicileri Analizlerinde Kullanılan Değişkenlere İlişsin PP Birim Kök Testi

\begin{tabular}{|c|c|c|c|c|c|c|}
\hline \multicolumn{7}{|c|}{ BİRİM KÖK TABLOSU (PP) } \\
\hline \multicolumn{7}{|c|}{ Düzeyde Durağanlı } \\
\hline
\end{tabular}


TÜRKMEN \& ŞENOCAK

\begin{tabular}{|c|c|c|c|c|c|c|}
\hline Sabitsiz ve Trendsiz & t-istatistiği & -1.3911 & -2.4541 & 3.7550 & -0.4193 & 4.0016 \\
\hline & Olasılık & 0.1499 & 0.0156 & 0.9999 & 0.5250 & 0.9999 \\
\hline & & n0 & $* *$ & n0 & n0 & n0 \\
\hline \multicolumn{7}{|c|}{ Birinci Farkta Durağanlık } \\
\hline & & $\mathbf{d}(\mathbf{L M})$ & $\mathbf{d}(\mathbf{L X})$ & d(LEU) & $\mathbf{d}(\mathbf{L E})$ & $\mathbf{d}(\mathbf{L Y})$ \\
\hline \multirow[t]{3}{*}{ Sabitli } & t-istatistiği & -36.3759 & -25.6691 & -14.4217 & -5.4408 & -27.1583 \\
\hline & Olasilık & 0.0001 & 0.0001 & 0.0000 & 0.0001 & 0.0001 \\
\hline & & $* * *$ & $* * *$ & $* * *$ & $* * *$ & $* * *$ \\
\hline \multirow[t]{3}{*}{ Sabitli ve Trendli } & t-istatistiği & -49.5592 & -35.4828 & -14.2029 & -9.5044 & -27.5199 \\
\hline & Olasılık & 0.0000 & 0.0000 & 0.0000 & 0.0000 & 0.0000 \\
\hline & & $* * *$ & $* * *$ & $* * *$ & $* * *$ & $* * *$ \\
\hline \multirow[t]{3}{*}{ Sabitsiz ve Trendsiz } & t-istatistiği & -26.8992 & -23.8010 & -9.6332 & -5.5292 & -13.3506 \\
\hline & Olasılık & 0.0000 & 0.0000 & 0.0000 & 0.0000 & 0.0000 \\
\hline & & $* * *$ & $* * *$ & $* * *$ & $* * *$ & $* * *$ \\
\hline
\end{tabular}
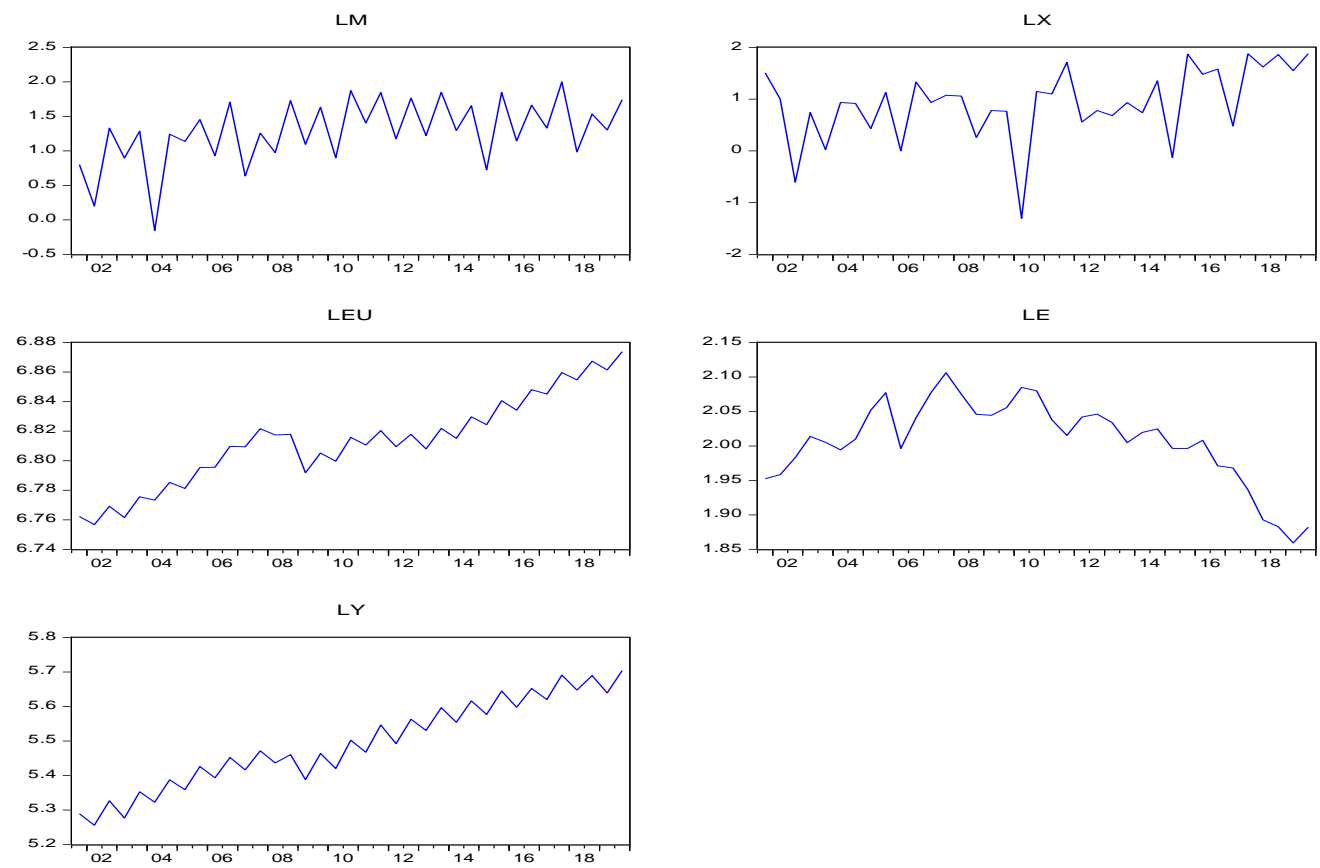

Şekil 1. İthalat ve İhracat Analizinde Kullanılan Değişkenlere Ait Grafikler

Analizde kullanılacak verilerin tümünün I(0) yani düzeyde durağan olması halinde sıradan en küçük kareler uygulanabilecekken, hepsinin I(1) yani 1. farkta durağan olması durumunda ise eş bütünleşme analizi yapılabilirdi. Ancak verilerin bir kısmının düzeyde durağan, bir kısmının 1400 
ise 1. farkta durağan olması sebebiyle belirleyicilerin analizlerinde ARDL yöntemiyle uzun dönem ilişkilerin belirlenmesine ve devamında hata düzeltme modelleriyle, bu ilişkilerdeki kısa dönem dinamiklerin gözlemlenmesine karar verilmiştir.

Reel değişkenlerin çoğunluğunun cari değerler içermesinden dolayı, analizlerde döviz kuru değişkeni olarak reel efektif döviz kuru kullanılmıştır. Bir birim ülke parasının diğer bir ülke parası cinsinden fiyatı, döviz kuru olarak adlandırılmaktadır. Nominal efektif döviz kuru Türkiye'nin diş ticaretinde büyük pay sahibi olan ülkelerin para birimlerinden oluşan sepete göre, Türk lirasının ağırlıklı ortalama değeridir. Ağırlıklar ikili ticaret akımlarının kullanılmasıyla belirlenmektedir. Nominal efektif döviz kurundaki nispi fiyat etkilerinin arındırılması ile elde edilen değer ise reel efektif döviz kurudur. Türkiye Cumhuriyet Merkez Bankası (TCMB) tarafından hesaplanan reel efektif döviz kuru endeksleri, Türkiye'nin fiyat düzeylerinin dış ticaret yapılan ülkelerin fiyat düzeylerine oranının ağırlıklı geometrik ortalaması alınarak hesaplanmaktadır (TCMB, 2020a).

Tablo 3. İhracat İçin Zaman Serisi Tahmin Sonuçları

\begin{tabular}{|c|c|c|c|c|c|}
\hline \multicolumn{3}{|c|}{ Kısa Dönem } & \multicolumn{3}{|c|}{ Uzun Dönem } \\
\hline Değişken & Katsayı & t-değeri & Değişken & Katsayı & t-değeri \\
\hline $\mathrm{D}(\mathrm{LEU})$ & 0,817 & 0.0590 & LEU & $28.793 * * *$ & 2.941 \\
\hline D(LEU(-1)) & $-31.449 * *$ & -2.386 & LE & -0.925 & -0.573 \\
\hline $\mathrm{D}(\mathrm{LE})$ & -1.215 & -0.564 & FFP & $0.769 * *$ & 2.034 \\
\hline $\mathrm{D}(\mathrm{FFP})$ & $1.010 * *$ & 2.164 & RST & $0.784 * *$ & 2.316 \\
\hline $\mathrm{D}(\mathrm{RST})$ & $1.030 * *$ & 2.456 & TOUR & $-0.377 * *$ & -2.203 \\
\hline D(TOUR) & $-0.495 * *$ & -2.213 & $\mathrm{C}$ & $-191.870 * * *$ & -2.895 \\
\hline D(@TREND)) & $-0.135 * * *$ & -2.816 & @TREND & $-0.103 * * *$ & -2.652 \\
\hline CointEq(-1) & $-1.313 * * *$ & -9.016 & & & \\
\hline \multicolumn{6}{|c|}{ Analizlerin İstatistiksel Test Sonuçları } \\
\hline \multicolumn{3}{|c|}{ Model } & \multicolumn{2}{|c|}{$\operatorname{ARDL}(1,2,0)$} & \\
\hline \multicolumn{3}{|c|}{ ARDL Bounds Test (F İstatistiği) } & \multicolumn{2}{|c|}{$29.564 * * *$} & \\
\hline \multicolumn{3}{|c|}{ Jarque-Bera Normallik Testi } & \multicolumn{2}{|c|}{$1.232(\mathrm{n} 0)$} & \\
\hline \multicolumn{3}{|c|}{ Breusch-Godfrey LM Testi } & \multicolumn{2}{|c|}{$0.905(\mathbf{n 0})$} & \\
\hline
\end{tabular}

İhracat için zaman serisi tahmin sonuçlarının bulunduğu Tablo 3 'te; uygun gecikmeleri içeren analizin tahmini amacıyla ARDL yöntemi kullanılarak, Schwarz Bilgi Kriteri'ne uygun gecikmelerin tahmini yapılmıştır. ARDL Bounds Test sonucunda hesaplanan F değerinin kritik değerden büyük olması halinde, uzun dönemde analizdeki değişkenlerin ilişkisiz olduğu hipotezi reddedilerek, söz konusu değişkenler arasında uzun dönemli eş bütünleşik bir ilişkinin varlığından söz edilebilir (Pesaran vd., 2001: 290; Türkmen, 2018: 99). Yapılan analiz neticesinde Bounds Test sonucunun \%1 kritik değerden büyük olduğu belirlenmiştir. Yani değişkenler arasında uzun dönemli eş bütünleşik bir ilişkinin mevcut olduğu görülmektedir. Hata terimlerinin normal dağıldığ 1 ve otokorelasyon veya seri korelasyon problemi göstermediği Jarque-Bera Normallik ve Breusch-Godfrey LM testleriyle gözlemlenmiştir. Ayrıca değişkenlerin trend içerdiği gözlemlendiğinden analize trend değişkeni de katılmıştır. Uzun dönem ilişkiler için yapılan ARDL Bound Testi ve kısa dönem dinamikleri gözlemlemek için yapılan Hata Düzeltme Modeli analizleri sonucu Tablo 3'te elde edilen bulgulara göre değişkenlerin kısa ve uzun dönemli ilişkileri incelendiğinde: 
Kısa dönemde dış pazar büyüklüğünü temsil eden Avrupa Birliği GSYH D(LEU) ile bağımlı değişken olan ihracat (LX) arasında pozitif yönlü ilişki bulunmuş, yani bu değiş̧kende yaşanacak bir artışın futbolcu ihracatını da artıracağı tespit edilmiş ancak bu ilişkinin istatistiki bakımdan anlamlı olmadığı görülmüştür. Her ne kadar anlamlı bir ilişki göstermese de ilişkinin yönü açısından değişkenler arasında kısa dönem ilişkiyi işaret etmektedir. Uzun dönemde ise \%1 önem seviyesinde Avrupa Birliği GSYH (LEU) ile LX arasında pozitif yönlü ve anlamlı bir ilişki mevcuttur. Diğer değişkenler sabitken LEU'daki \%1'lik değişim LX üzerinde \%28.79'luk pozitif etkiye neden olmaktadır. Bu sonuca göre uzun dönemde Avrupa Birliği GSYH'de yaşanacak bir artış futbolcu ihracatında da artışa sebep olmaktadır. Ünsal (2017) çalışmasında, ihracatın yurt dışı GSYH ile doğru orantılı olarak değiştiğini belirtmiştir (Ünsal, 2017: 398-400). Analiz sonuçlarına göre de bu teorik beklenti ile aynı yönlü bulgular tespit edilmiştir. $\mathrm{D}(\mathrm{LEU})$ değişkeninin bir önceki dönem değerini temsil eden $\mathrm{D}(\mathrm{LEU}(-1))$ ile $\mathrm{LX}$ arasında $\% 5$ önem seviyesinde negatif yönlü bir ilişkinin var olduğu ve bu ilişkinin istatistiki bakımdan anlamlı olduğu tespit edilmiştir. Diğer değişkenler sabitken $\mathrm{D}(\mathrm{LEU})$ 'da yaşanan \%1'lik artış LX üzerinde \%31.44 azalmaya sebep olmaktadır. Kısa dönem için Avrupa Birliği GSYH'nin bir önceki döneminde yaşanan bir artış Türkiye Süper Lig'in ihracatı üzerinde negatif bir etkiye sebep olmaktadır.

Hem kısa hem de uzun dönemde reel efektif döviz kuru (D(LE) ve LE) değişkeni ile LX arasında negatif yönlü ilişki bulunmuş, yani bu değişkendeki bir artışın futbolcu ihracatını azalttığı tespit edilmiş olmasına rağmen bu ilişkinin istatistiki bakımdan anlamlı olmadığı belirlenmiştir. Ancak bu sonuçlara göre anlamlı bir ilişki bulunamamış olsa da ilişkinin yönü değişkenler arasında kısa ve uzun dönemdeki ilişskiyi işaret etmektedir. Reel efektif döviz kurundaki artışlar nominaldeki değişimin aksine TL'nin reel olarak değer kazandığını, diğer bir ifadeyle Türkiye'de üretilen malların yabancı mallar cinsinden fiyatının arttı̆̆ını göstermektedir. ${ }^{2}$ Analiz sonuçlarına göre de teoriye uygun olarak reel efektif döviz kurunda yaşanacak herhangi bir artışın Türkiye Süper Lig'in ihracatında azalmaya sebep olduğu görülmektedir.

Kısa ve uzun dönemde Finansal Fair Play kuralları (D(FFP) ve FFP) ile LX arasında \%5 önem seviyesinde pozitif yönlü bir ilişki bulunduğu ve bu ilişkinin istatistiki olarak anlamlı olduğu tespit edilmiştir. Kısa dönemde diğer değişkenler sabitken D(FFP)'de yaşanan 1 birimlik artış LX üzerinde 1,01 birimlik artışa sebep olmaktadır. Uzun dönemde ise değişkenler sabitken FFP'de yaşanan 1 birimlik artı̧ LX'de 0,76 birimlik artış oluşturmaktadır. Bu sonuçlara göre FFP değişkeni Türkiye Süper Lig'in ihracatına hem kısa hem de uzun dönemde olumlu katkı sağlamıştır. Peeters ve Szymanski (2012), Flanagan (2013) ve Schubert vd., (2016) çalışmalarında, FFP'nin gelir-gider dengesini oluşturarak, finansal istikrarın sağlanmasında etkili olduğunu tespit etmişlerdir. Bu sonuçlar Türkiye Süper Lig için ulaşılan sonuçları desteklemektedir.

\footnotetext{
${ }^{2}$ Analizde kullanılan reel kur hesaplaması temelde aşağıda yer alan formüle dayanmaktadır.

$\mathbf{R}=\mathbf{P} / \boldsymbol{e} \mathbf{P} *$

Denklemde bulunan " $R$ " reel döviz kuru, " $P$ " ulusal fiyat düzeyi, " $e$ " nominal kur ve " $P$ *" yabancı ülke fiyat düzeyini ifade etmektedir. Dolayısıyla reel kurdaki artışlar TL'nin reel değerinin arttığını, reel kurdaki azalmalar ise TL'nin reel değerinin düştügünü ifade etmektedir (TCMB, 2020b). Bu nedenle reel efektif kur ile nominal kur ters ilişki göstermektedir.
} 
Hem kısa hem de uzun dönemde yabancı futbolcu sınırlaması kuralı (D(RST) ve RST) ile LX arasında \%5 önem seviyesinde pozitif yönlü bir ilişki olduğu ve bu ilişkinin istatistiki olarak anlamlı olduğu belirlenmiştir. Kısa dönemde diğer değişkenler sabitken D(RST)'de yaşanan 1 birimlik artış LX üzerinde 1.03 birimlik artışa yol açmıştır. Uzun dönemde ise diğer değişkenler sabitken RST'de yaşanan 1 birim artış LX'de 0,78 birim artışa sebep olmaktadır. Bu sonuçlara göre uygulanan yabancı futbolcu kuralının Türkiye Süper Lig'in ihracatını kısa ve uzun dönemde olumlu etkilediği görülmektedir.

Hem kısa hem de uzun dönemde Türkiye A Milli Futbol Takımı'nın uluslararası turnuvalara katılma başarısı göstermesi (D(TOUR) ve TOUR) ile LX arasında \%5 önem seviyesinde negatif yönlü bir ilişkinin bulunduğu ve bu ilişkinin istatistiki olarak anlamlı olduğu tespit edilmiştir. Kısa dönemde diğer değişkenler sabitken D(TOUR)'da yaşanan 1 birimlik artış LX üzerinde 0.49 birimlik azalmaya neden olmaktadır. Uzun dönemde ise diğer değişkenler sabitken TOUR'da yaşanan 1 birim artış LX üzerinde 0.37 birim azalmaya yol açtığ1 görülmektedir.

Hata düzeltme modeliyle kısa dönemli ilişkilerin ihracat için bulguları incelendiğinde, hata düzeltme katsayısı (CointEq(-1)) negatif yönlü ve istatistiki olarak \%1 önem seviyesinde anlamlıdır. Katsayının negatif yönlü ve istatistiki olarak anlamlı olması, kısa dönemde oluşan dengeden uzaklaşma durumlarının, uzun dönem için tekrar dengeye yöneldiğine işaret etmektedir. -1.31 olan katsayı tahmin değeri ise kısa dönemde oluşan şokların, \%131 hızla dalgalı olarak uzun dönemde denge durumuna ulaştığını göstermektedir.

Tablo 4: İthalat İçin Zaman Serisi Tahmin Sonuçları

\begin{tabular}{|c|c|c|c|c|c|c|}
\hline \multicolumn{4}{|c|}{ Kısa Dönem } & \multicolumn{3}{|c|}{ Uzun Dönem } \\
\hline Değișken & Katsayı & \multicolumn{2}{|c|}{ t-değeri } & Değişken & Katsayı & t-değeri \\
\hline $\mathrm{D}(\mathrm{LM}(-1))$ & $0.523 * * *$ & \multicolumn{2}{|c|}{3.146} & LY & $-6.974 *$ & -1.724 \\
\hline $\mathrm{D}(\mathrm{LY})$ & 4.010 & \multicolumn{2}{|l|}{1.187} & LE & $3.657 * *$ & 3.243 \\
\hline $\mathrm{D}(\mathrm{LY}(-1))$ & $-9.864 * * *$ & \multicolumn{2}{|l|}{-2.970} & RST & -0.082 & -0.639 \\
\hline $\mathrm{D}(\mathrm{LY}(-2))$ & 6.914* & \multicolumn{2}{|l|}{1.690} & FFP & -0.471 & -1.391 \\
\hline $\mathrm{D}(\mathrm{LY}(-3))$ & 8.593 & \multicolumn{2}{|l|}{1.448} & $\mathrm{C}$ & 29.678 & 1.506 \\
\hline $\mathrm{D}(\mathrm{LE})$ & 1.214 & \multicolumn{2}{|l|}{0.794} & @TREND & $0.134 * *$ & 2.103 \\
\hline $\mathrm{D}(\mathrm{LE}(-1))$ & $-4.145 * * *$ & \multicolumn{2}{|l|}{-2.673} & & & \\
\hline $\mathrm{D}(\mathrm{RST})$ & -0.118 & \multirow{2}{*}{\multicolumn{2}{|c|}{$\begin{array}{l}\frac{-0.618}{-1.373} \\
\end{array}$}} & & & \\
\hline $\mathrm{D}(\mathrm{FFP})$ & -0.677 & & & & & \\
\hline D(@TREND) & $0.192 * *$ & \multicolumn{2}{|l|}{2.041} & & & \\
\hline CointEq(-1) & $-1.437 * * *$ & -6.343 & & & & \\
\hline \multicolumn{7}{|c|}{ Analizlerin İstatistiksel Test Sonuçları } \\
\hline \multicolumn{3}{|c|}{ Model } & \multicolumn{4}{|c|}{$\operatorname{ARDL}(2,4,2)$} \\
\hline \multicolumn{3}{|c|}{ ARDL Bounds Test (F İstatistiği) } & \multicolumn{4}{|c|}{$14.799 * * *$} \\
\hline \multicolumn{3}{|c|}{ Jarque-Bera Normallik Testi } & \multicolumn{4}{|c|}{$3.004(\mathbf{n} 0)$} \\
\hline \multicolumn{3}{|c|}{ Breusch-Godfrey LM Testi } & \multicolumn{4}{|c|}{$0.458(\mathbf{n 0})$} \\
\hline \multicolumn{7}{|c|}{$\begin{array}{l}\text { Not: }(* * *) 1 \% \text { önem seviyesinde anlamll11k; }(* *) 5 \% \text { önem seviyesinde anlamll11k; }\left(^{*}\right) 10 \% \text { önem seviyesinde } \\
\text { anlamll1k ve (n0) ise anlamlı olmama durumunu temsil etmektedir. }\end{array}$} \\
\hline
\end{tabular}

İthalat için zaman serisi tahmin sonuçlarının yer aldığı Tablo 4'te; ihracat için de uygulandığı gibi uygun gecikmeleri içeren analizin tahmini amacıyla ARDL yöntemi kullanılarak, Schwarz Bilgi Kriteri'ne uygun gecikmelerin tahmini yapılmıştır. Yapılan analizde Bounds Test sonucunun \%1 kritik değerden büyük olduğu, değişkenler arasında uzun dönemli eş bütünleşik bir ilişki olduğu gözlemlenmiştir. İhracatta olduğu gibi ithalat için de yapılan testler sonucunda hata terimlerinin normal dağıldığı ve otokorelasyon veya seri korelasyon problemi 
göstermediği görülmüştür. İhracat için yapılan tahmin sonuçlarında olduğu gibi ithalatta da kısa dönem dinamikleri elde etmek amacıyla Hata Düzeltme Modeli kullanılmış ve sonuçlara yine Tablo 4'de yer verilmiştir. Değişkenlerin trend içerdiği gözlemlendiğinden analize trend değişkeni de katılmıştır. Belirlenen sonuçlara göre değişkenlerin kısa ve uzun dönemlerdeki ilişsileri incelendiğinde:

Kısa dönemde bir önceki dönem ithalat miktarını gösteren $\mathrm{D}(\mathrm{LM}(-1))$ ile bağımlı değişken olan ithalat (LM) arasında \%1 önem seviyesinde pozitif yönlü bir ilişkinin olduğu ve bu ilişkinin istatistiki olarak anlamlı olduğu tespit edilmiştir. Diğer değişkenler sabitken D(LM(-1))'de yaşanan \%1'lik artışın LM üzerinde \%0,52'lik bir artışa sebep olduğu gözlenmektedir. Bu sonuca göre Türkiye Süper Lig'in ithalatında bir önceki dönemin ithalat miktarının pozitif etki oluşturduğu görülmektedir.

İç pazar büyüklüğünü temsil eden Türkiye GSYH'nin kısa dönemde D(LY) ile LM arasında pozitif yönlü ilişki bulunmasına, yani bu değişkendeki bir artışın futbolcu ithalatını da artırdığı tespit edilmesine rağmen bu ilişkinin istatistiki bakımdan anlamlı olmadığı görülmüştür. Bu sonuçlara göre anlamlı bir ilişki bulunamamış olsa da ilişkinin yönü değişkenler arasında kısa dönemdeki ilişkiyi işaret etmektedir. Uzun dönemde ise $\% 10$ önem seviyesinde Türkiye GSYH (LY) ile LM arasında negatif yönlü bir ilişkinin olduğu ve bu ilişkinin istatistiki olarak anlamlı olduğu belirlenmiştir. Diğer değişkenler sabitken bu değişkende yaşanan \%1 artış, LM'de \%6,97 azalmaya sebep olmuştur. Ünsal (2017) çalışmasında, ithalatın GSYH ile doğru, reel döviz kuru ile ters orantılı olarak değiştiğini belirtmiştir (Ünsal, 2017: 396-397). Ancak gerçekleştirilen analizde bu teorik beklentiye ters olarak uzun dönemde negatif bir etkinin varlığı tespit edilmiştir. Bu sonuca göre uygulanan yabancı futbolcu sınırlamalarının doğal bir sonucu olarak gelir artışının dış pazardan ziyade yerli futbolculara yönelttiği düşünülebilecektir.

Kısa dönemde Türkiye GSYH'nin bir önceki dönemini temsil eden D(LY(-1)) ile LM arasında \%1 önem seviyesinde negatif yönlü bir ilişkinin var olduğu ve bu ilişkinin istatistiki olarak anlamlı olduğu tespit edilmiştir. Diğer değişkenler sabitken bu değişkende yaşanan \%1 artış, LM'de \%9.86 azalmaya sebep olmuştur. Türkiye Süper Lig'in ithalatında bir önceki dönem Türkiye GSYH'nin olumsuz etki oluşturduğu görülmektedir. Kısa dönemde Türkiye GSYH'nin iki önceki dönemini temsil eden D(LY(-2)) ile LM arasında \%10 önem seviyesinde pozitif yönlü bir ilişkinin olduğu ve bu ilişkinin istatistiki olarak anlamlı olduğu tespit edilmiştir. Diğer değiş̧kenler sabitken bu değgişkende yaşanan \%1 artış, LM'de \%6.91 artış oluşturmuştur. Kısa dönemde Türkiye GSYH'nin üç önceki dönemini temsil eden D(LY(-3)) ile LM arasında pozitif yönlü bir ilişki olmasına, yani bu değişkendeki bir artışın futbolcu ithalatını artırdığı tespit edilmesine rağmen bu ilişkinin istatistiki olarak anlamlı olmadığ1 belirlenmiştir. Her ne kadar anlamlı bir ilişki bulunamamış olsa da ilişkinin yönü değişkenler arasında bulunan kısa dönemdeki ilişkiyi işaret etmektedir.

Kısa dönemde reel efektif döviz kuru D(LE) ile LM arasında pozitif yönlü bir ilişki olmasına, yani bu değişkendeki bir artışının futbolun ithalatını artırdığı tespit edilmesine rağmen bu ilişkinin istatistiki olarak anlamlı olmadığı görülmektedir. Uzun dönemde ise reel efektif döviz kuru (LE) ile LM arasında \%5 önem seviyesinde pozitif yönlü bir ilişkinin bulunduğu ve bu ilişkinin istatistiki olarak anlamlı olduğu tespit edilmiştir. Diğer değişkenler sabitken bu değişkende yaşanan \%1 artış, LM'de \%3.65 artış oluşturmuştur. Analiz sonuçlarına göre kısa dönemde doğru yönlü bir ilişki bulunan değişkenler arasında anlamlı bir ilişki bulunamamış, uzun dönemde ise değişkenler arasında doğru yönlü ve anlamlı bir ilişki bulunmuştur. Kısa 1404 
dönemde reel efektif döviz kurunun bir önceki dönem değerini temsil eden $\mathrm{D}(\mathrm{LE}(-1))$ ile LM arasında \%1 önem seviyesinde negatif yönlü bir ilişkinin olduğu ve bu ilişkinin istatistiki olarak anlamlı olduğu tespit edilmiştir. Diğer değişkenler sabitken bu değişkende yaşanan $\% 1$ artış, LM'de \%4.14 azalmaya sebep olmuştur. Bu sonuca göre kısa dönemde bir önceki dönem reel efektif döviz kurunun Türkiye Süper Lig'in ithalatı üzerinde olumsuz bir etkisinin olduğu görülmektedir.

Hem kısa hem de uzun dönemde yabancı futbolcu sınırlaması kuralı (D(RST) ve RST) ve Finansal Fair Play kuralları (D(FFP) ve FFP) ile LM arasında negatif yönlü bir ilişki olmasına, yani bu değişkenlerdeki bir artışın futbolun ithalatında azalmaya sebep olduğunun tespit edilmesine rağmen bu ilişkinin istatistiki olarak anlamlı olmadığı görülmektedir. Bu sonuçlara göre anlamlı bir ilişki bulunamamış olsa da ilişkinin yönü değişkenler arasında kısa ve uzun dönemdeki ilişkiyi işaret etmektedir.

Hata düzeltme modeliyle kısa dönemli ilişkilerin ithalat için bulguları incelendiğinde, hata düzeltme katsayısı (CointEq(-1)) negatif yönlü ve istatistiki olarak \%1 önem seviyesinde anlamlıdır. Katsayının negatif yönlü ve istatistiki olarak anlamlı olması, kısa dönemde oluşan dengeden uzaklaşma durumlarının, uzun dönem için tekrar dengeye yöneldiğini ifade etmektedir. -1,43 olan katsayı tahmin değeri ise kısa dönemde oluşan şokların, \%143 hızla dalgalı olarak uzun dönemde denge durumuna ulaştığını göstermektedir.

\section{SONUC}

Futbolun endüstriyelleşmesi futbol kulüplerini birer ticari işletme haline dönüştürmüştür. Bunun neticesinde, şirketleşen kulüpler piyasalara uyum sağlayarak belirli koşullar altında faydalarını maksimum kılmak ve kazançlarını en yüksek seviyeye çıkarmak istemektedirler. Küreselleşme ve futbol kulüplerinin şirketleşmesiyle birlikte futbolcu ithalat ve ihracatlarında büyük artışlar yaşanmıştır. Temel hedefi başarı kazanmak olan futbol kulüplerinin aynı zamanda ekonomik istikrarlarını da sürdürmeleri zorunludur. Bu sebeple futbol kulüpleri, başarı kazanmak ve önemli seviyelere ulaşan dış ticaret işlemleri sebebiyle finansal sürdürülebilirlik adına gelir-gider dengelerini sağlamalıdırlar.

Türkiye'nin 2001-2019 yılları arasındaki futboldaki dış ticaretinin belirleyicilerinin tespit edilmesi amacıyla uygulanacak analizlerdeki model seçiminin belirlenmesi için öncelikle değişkenlere birim kök testleri uygulanmış, ardından testin devamı için karar vermek amacıyla değerlendirmeler yapılmıştır. Verilerin bir kısmının düzeyde durağan, bir kısmının ise 1. farkta durağan olması sebebiyle, belirleyicilerin analizlerinde ARDL yöntemiyle uzun dönem ilişkilerin belirlenmesine ve devamında hata düzeltme modelleriyle bu ilişkilerdeki kısa dönem dinamiklerin gözlemlenmesine karar verilmiştir. Analizler neticesinde Bounds test sonucunun \%1 kritik değerden büyük olduğu gözlemlenmiştir. Yani değişkenler arasında uzun dönemli eş bütünleşik bir ilişki mevcuttur. Elde edilen analiz sonuçlarına göre;

Avrupa Birliği GSYH Türkiye Süper Lig'in ihracatı üzerinde kısa dönemde anlamlı bir etki oluşturmazken, uzun dönemde pozitif yönlü önemli bir etkiye sebep olmaktadır. Bu sonuca göre uzun dönemde Avrupa Birliği GSYH'de yaşanacak bir artış futbolcu ihracatında önemli bir artışa sebep olmaktadır. Kısa dönem için Avrupa Birliği GSYH'nin bir önceki döneminde yaşanan bir artış ise Türkiye Süper Lig'in ihracatı üzerinde negatif bir etkiye sebep olmaktadır. Bu sonuç özellikle dönemsel olarak gecikmeli değerlerin ihracatı azaltıcı etki yaptığı ve AB'nin gelir artışlarına rağmen transferlerini Türkiye'den yapmayı tercih etmediği bulgusunu desteklemektedir. Kısa ve uzun dönemde reel efektif kur futbolcu ihracatı üzerinde anlamlı bir etki oluşturmazken FFP değişkeni Türkiye Süper Lig'in ihracatına hem kısa hem de uzun 
dönemde olumlu katkı sağlamaktadır. FFP kuralı ile birlikte transferlerde al-sat dengesinin sağlanma zorunluluğunun getirilmesi, futbol kulüplerini futbolcu transferi yapabilmek için futbolcu satışı gerçekleştirmek zorunda bırakmıştır. Bu durum FFP'nin futbolcu ihracatında artışa sebep olmasının temel nedeni olarak gösterilebilir. Uygulanmakta olan yabancı futbolcu kuralının ise Türkiye Süper Lig'in ihracatına hem kısa hem de uzun dönemde olumlu katkı sağladığı görülmektedir. Yabancı futbolcu serbestliği olarak da belirtilen, kulüplerin kadrolarında 14 yerli futbolcu bulundurmasını zorunlu tutan söz konusu bu kural ile birlikte kulüplerin ilk 11'lerinde yerli futbolcu oynatma zorunluluğu ortadan kalkmıştır. Bu durum neticesinde talep fazlalığı nedeniyle yüksek ücretler alan yerli futbolcuların, bu kuralın ardından talepte yaşanan azalmayla birlikte ücretlerinde düşüşler meydana gelmiştir. Ücretlerdeki normalleşmeyle birlikte yerli futbolcular uluslararası rekabete dahil olarak Avrupa'ya transfer olmaya başlamışlardır. Uygulanmakta olan kuralın arz-talep dengesini sağlaması sebebiyle futbolcu ihracatını artırdığı söylenebilecektir. Turnuvaya katılma başarısı göstermenin ihracat rakamları üzerinde olumlu etki oluşturması beklenirken, elde edilen sonuçlara göre Türkiye A Milli Futbol Takımı'nın turnuvalara katılma başarısı göstermesi Türkiye Süper Lig'in ihracatı üzerinde kısa ve uzun dönemde olumsuz etki oluşturmuştur. Turnuvalara sürekli katılım başarısının gösterilememesi ve yabancı futbolcu sınırlamalarından dolayı başarılı yerli futbolcuların yurt dışına transfer olmak yerine yüksek ücretle yurt içindeki büyük kulüplere transfer olmayı tercih etmeleri bu durumun nedenleri olarak tahmin edilebilir. Türkiye Süper Lig'in ithalatında bir önceki dönemin ithalat miktarının pozitif etki oluşturduğu belirlenmiştir. Bu sonuç Türkiye'ye gelen yabancı futbolcuların yeni futbolculara referans olduğunu ve kulüplerinden memnun olan futbolcuların başka futbolcuların transferlerine aracı olmalarını ifade edebilmektedir. Türkiye GSYH'nin futbolcu ithalatı üzerinde kısa dönemde anlamlı bir etkisi tespit edilememişken, uzun dönemde negatif bir etkinin varlığ tespit edilmiştir. Gelir artışının dış pazardan ziyade yerli futbolculara yönelttiği görülmektedir. Bu da uzun yıllar uygulanan yabancı futbolcu sınırlamalarının doğal bir sonucu olarak değerlendirilebilecektir. Kulüpler artan gelirlerini, yurt dışı transferler yerine yüksek fiyat düzeyine sahip olan iç piyasada kullanmak zorunda kalmışlardır. Türkiye Süper Lig'in ithalatında bir önceki dönem Türkiye GSYH'nin olumsuz etki oluşturduğu belirlenmiştir. Bu sonuç, Türkiye'de hem ara hem de yaz dönemi transferlerinde iç piyasanın daha çok tercih edildiğini göstermektedir. Türkiye Süper Lig'in ithalatında iki önceki dönem Türkiye GSYH'nin olumlu etki oluşturduğu tespit edilmiştir. Bu sonuca göre ithalatın gelirden pozitif yönde etkilenmesi için en az iki dönemlik bir gecikmenin olması gerektiği görülmüş, yani bir önceki yılın gelirinin olumlu etki oluşturduğu tespit edilmiştir. Türkiye Süper Lig'in ithalatında üç önceki dönem Türkiye GSYH'nin ise futbolcu ithalatını değiştirmede anlamlı bir etki oluşturmadığı görülmektedir. Elde edilen sonuçlara göre kısa dönemde reel efektif döviz kurunun Türkiye Süper Lig'in ithalatı üzerinde anlamlı bir etki oluşturmadığı ancak uzun dönemde ise pozitif bir etkinin var olduğu belirlenmiştir. Yani reel efektif kurdaki bir iyileşmenin futbolun ithalatını artırdığı anlaşılmaktadır. Kısa dönemde bir önceki dönem reel efektif döviz kurunun Türkiye Süper Lig'in ithalatı üzerinde olumsuz bir etkisinin olduğu belirlenmiştir. $\mathrm{Bu}$ sonuca göre bir önceki dönem reel efektif döviz kurunda yaşanan bir iyileşmenin futbolun ithalatını azalttığı görülmektedir. Yabancı futbolcu sınırlaması ve FFP kurallarının ise Türkiye Süper Lig'in ithalatı üzerinde anlamlı bir etki oluşturmadığı tespit edilmiştir.

Değişkenlerin dış ticaret dengesi üzerindeki etkileri incelendiğinde; kısa dönemde Türkiye GSYH'nin ve reel efektif döviz kurunun bir önceki dönem değerlerinin futbolcu ithalatını azaltarak, Türkiye Süper Lig'in futboldaki dış ticaret dengesi üzerinde olumlu bir etki 1406 
oluşturduğu görülmektedir. Avrupa Birliği GSYH'nin bir önceki dönem değeri futbolcu ihracatını azaltarak, bir önceki dönem ithalat miktarı ve Türkiye GSYH'nin iki önceki dönem değerinin ise futbolcu ithalatını artırarak, Türkiye Süper Lig'in futboldaki dış ticaret dengesi üzerinde olumsuz bir etki oluşturduğu gözlemlenmiştir. Uzun dönemde Avrupa Birliği GSYH ihracatı artırıcı etkisinden dolayı, Türkiye GSYH miktarı ise ithalatı azaltıcı etkisinden dolay1 Türkiye Süper Lig'in futboldaki dış ticaret dengesi üzerinde olumlu bir etkiye sahipken, reel efektif döviz kurunun ithalatı artırması dolayısıyla Türkiye Süper Lig'in futboldaki dış ticaret dengesi üzerinde olumsuz bir etkiye sahip olduğu tespit edilmiştir. Hem uzun hem de kısa dönemde Türkiye A Milli Futbol Takımı'nın turnuvalara katılma başarısı göstermesi, futbolcu ihracatını azaltıcı etkinden dolayı Türkiye Süper Lig'in futboldaki dış ticaret dengesi üzerinde olumsuz bir etki oluşturduğu belirlenmiştir. Finansal Fair Play kuralları ve uygulanan yabanc1 futbolcu kuralı ise futbolcu ihracatını artırıcı etkilerinden dolayı Türkiye Süper Lig'in futboldaki dış ticaret dengesi üzerinde olumlu bir etki oluşturmuşlardır.

\section{KAYNAKÇA}

AKALIN, A. (2018). Galatasaray, Fenerbahçe, Beşiktaş Spor Kulüpleri ile Manchester United Spor Kulübünün Finansal Raporlarının Analizi ve Finansal Fair Play Açısından Değerlendirilmesi. Yüksek Lisans Tezi. Ankara: Atılım Üniversitesi Sosyal Bilimler Enstitüsü.

AKKAYA, C. (2008). “Küreselleşme ve Futboldaki Dönüşüm”. ETHOS: Felsefe ve Toplumsal Bilimlerde Diyaloglar, 1(4), 1-15.

AKŞAR, T. (2005). Endüstriyel Futbol. İstanbul: Literatür Yayınları.

AKŞAR, T. ve KUTLU, M. (2006). Futbol Ekonomisi. İstanbul: Literatür Yayınları.

AY, Ş. (2016). Futbol Endüstrisi ile Bölgesel Kalkınmanın Sağlanması: Siirt İli Örneği. (Yüksek Lisans Tezi). Siirt: Siirt Üniversitesi Sosyal Bilimler Enstitüsü.

AYDIN, E. (2008). Futbol Ekonomisi: 2 Ülke Kıyaslaması (İngiltere ve Türkiye). Yüksek Lisans Tezi. İstanbul: Marmara Üniversitesi Sosyal Bilimler Enstitüsü.

BURAIMO, B., SIMMONS, R. \& SZYMANSKI, S. (2006). "English Football”. Journal of Sports Economics, 7(1), 29-46.

ÇAKMAK, G. (2018). Süper Lig'deki Seyirci Azalmasının Nedenleri ile Futbol Taraftarlarının E-Bilet Uygulamasına Bakış Açılarının Araştırılması. Yüksek Lisans Tezi. Sakarya: Sakarya Üniversitesi, Sosyal Bilimler Enstitüsü.

ÇAKMAK, U. D. (2019). Futbol Ekonomisi: Avrupa ve Türkiye Üzerine Karşılaştırmalı Bir İnceleme. Yüksek Lisans Tezi. İstanbul: İstanbul Üniversitesi Sosyal Bilimler Enstitüsü.

DEMİ, M. (2019). Profesyonel Futbolcu Piyasa Değeri ve Transfer Ücreti Arasındaki Değişkenliği Sağlayan Etkenlerin Değerlendirilmesi. Yüksek Lisans Tezi. İstanbul: Marmara Üniversitesi, Sağlık Bilimleri Enstitüsü.

DEVECİĞLU, S. (2004). "Halka Arz Edilen Spor Kulüplerinin Sportif Başarıları ile Piyasa Değerleri Arasındaki İlişki”. SPORMETRE Beden Eğitimi ve Spor Bilimleri Dergisi, 2(1), 11-18. 
DIMITROPOULOS, P. E. \& KOUMANAKOS, E. (2015). "Intellectual Capital and Profitability in European Football Clubs". International Journal of Accounting, Auditing and Performance Evaluation, 11(2), 202-220.

DOBSON, S. \& Goddard, J. (2001). The Economics of Football. Cambridge: University Press.

EKMEKÇİ DAĞLI, Y. A., EKMEKÇİ. R. \& İRMİŞ, A. (2013). "Küreselleşme ve Spor Endüstrisi”. Pamukkale Journal of Sport Sciences, 4(1), 91-117.

ELBİR, O. E. (2018). Futbol Endüstrisinde Markalaşmanın Türkiye ve Avrupa'daki Profesyonel Futbol Kulüplerinin Ekonomik Yapılarına Etkisinin İncelenmesi, Muğla: Muğla Sıtkı Koçman Üniversitesi, Sağlık Bilimler Enstitüsü.

EUROSTAT, (2020). https://ec.europa.eu/eurostat/.

FIŞNE, M. \& BARDAKÇI, S. (2019). “Taraftarların Bakış Açısıyla Türk Futbolunda Yabancı Oyuncu Sınırlamasına Yönelik Bir Araştırma”. Manas Sosyal Araştırmalar Dergisi, $8(1 / 1), 551-575$.

FLANAGAN, C. A. (2013). “A Tricky European Fixture: an Assessment of UEFA's Financial Fair Play Regulations and Their Compatibility with EU Law”. The International Sports Law Journal, 13, 148-167.

GÜLTEKİN S. \& SAVCI, M. (2008). Dış Ticaret İşlemleri Muhasebesi. Trabzon: Murathan Yayınevi.

GÜNGÖR, A. (2014). "Futbol Endüstrisinde Sportif Başarı ile Finansal Performans Arasındaki İlişkinin Analizi ve Türkiye Uygulaması”. İstanbul Üniversitesi Sosyal Bilimler Dergisi, 1, 16-36.

GÜREŞ, T. (2006). Futbol Ekonomisinde Naklen Yayın Gelirlerinin Bölüşümünün Analizi. Yüksek Lisans Tezi. Sakarya: Sakarya Üniversitesi Sosyal Bilimler Enstitüsü.

HORASAN, E. (2007). Futbol Kulüplerinin UEFA Mali Kriterlerine Uyumu, Denetimi ve Muhasebe Organizasyonu. Yüksek Lisans Tezi. İstanbul: Marmara Üniversitesi. Sosyal Bilimler Enstitüsü.

KARADENIZ, E., KOŞAN, L. \& KAHİLIOĞULLARI, S. (2014). "Borsa İstanbul'da İşlem Gören Spor Şirketlerinin Finansal Performansının Oran Yöntemiyle Analizi”. Ç.Ü. Sosyal Bilimler Enstitüsü Dergisi, 23(2), 129-144.

KELEŞ, A. (2019). "Bazı Futbol Kulüplerinin Yıllara Göre Gelir Kaynaklarının İncelenmesi”. International Journal of Academic Value Studies (JAVStudies), 5(4), 571-584.

KETBOĞA, M. (2020). Dış Ticaretin Yapısal Sorunları, Bu Sorunların Firmaların Faaliyetleri Üzerindeki Etkileri: Malatya Örneği. Doktora Tezi. Malatya: İnönü Üniversitesi, Sosyal Bilimleri Enstitüsü.

LEITAO, J. \& BAPTISTA. J, (2019). "Intellectual Capital Assets and Brand Value of English Football Clubs". International Journal of Sport Management and Marketing, 19(1-2), 177.

METE, M. (2013). Dış Ticaretin Belirleyicileri ve Türkiye Uygulaması. Doktora Tezi. Kahramanmaraş: Kahramanmaraş Sütçü İmam Üniversitesi, Sosyal Bilimler Enstitüsü. 
ORÇUN, Ç. \& DEMIRTAŞ, C. M. (2015). “Gelişen Futbol Ekonomisinde Taraftarların Kulüp Değerlerine Olan Bakış Açıları: Bucaspor Örneği”. Optimum Ekonomi ve Yönetim Bilimleri Dergisi, 2(1), 113-126.

ÖZEVIN, O. (2017). “UEFA Finansal Fair Play Düzenlemesinin Avrupa Futbol Kulüpleri Üzerindeki Etkisi: Avrupa 5 Büyük Ligi ve Türkiye Süper Ligi Üzerine Bir İnceleme’. Muhasebe ve Bilim Dünyası Dergisi, Spor ve Performans Araştırmaları Dergisi, 19(2), 479-508.

PEETERS, T. \& SZYMANSKI, S. (2012). "Vertical Restraints in Soccer: Financial Fair Play and the English Premier League". Working Papers University of Antwerp, Faculty of Business and Economics, 1169(028), 193-217.

PESARAN, M. H., SHIN Y., \& SMITH, R. J. (2001). "Bounds testing approaches to the analysis of level relationships". Journal Of Applied Econometrics, (16).3, 289-326.

RICCI, F., SCAFARTO, V., CELENZA, D., \& GILVARI, I. S. (2015). "Intellectual capital and business performance in professional football clubs: Evidence from a longitudinal analysis". Journal of Modern Accounting and Auditing, 11(9), 450-65.

SABAN, M. \& DEMİRCİ, F. (2016). “Finansal Fair Play ve Türkiye’deki Dört Büyük Futbol Kulübünün Uyum Düzeyinin İncelenmesi”. Mali Çözüm Dergisi, 26(137) 25-49.

SALEHNIA, B. \& NASRABADI, H. H. (2019). "Studying the İncome Sources of Isfahan Football Clubs with Entrepreneurial Approach", New Trends and Issues Proceedings on Humanities and Social Sciences 6(7), 42-46.

SANCHEZ, L. C., BARAJAS, Á., \& SÁNCHEZ-FERNÁNDEZ, P. (2019). Sports Finance: Revenue Sources and Financial Regulations in European Football. Sport (and) Economics, 327-366.

SCHUBERT, M., KÖNECKE, T., \& PITTHAN, H. (2016). The guardians of European football: UEFA Financial Fair Play and the career of social problems. European Journal for Sport and Society, 13(4), 296-324.

SEVİM, A. \& BÜLBÜL, S. (2017). "UEFA Finansal Fair Play (FFP) Kriterleri Kapsamında Türk Futbolunda Finansal Raporlamanın Önemi ve Bir Sistem Gerekliliği’. Kara Harp Okulu Bilim Dergisi, 27(2), 187-212.

SEYİDOĞLU, H. (2015). Uluslararası İktisat: Teori Politika ve Uygulama Geliştirilmiş 20. Baskı, İstanbul: Güzem Can Yayınları.

SOYGÜDEN, A. (2016). "Profesyonel Futbol Kulüplerinin Gelir Kaynaklarının İncelenmesi”. Ömer Halisdemir Üniversitesi İktisadi ve İdari Bilimler Fakültesi Dergisi, 9(4), 21-35.

SUNAY, H. (2004). “Spor Kulüplerinde Şirketleşme (Bazı Avrupa Ülkeleri ve Türkiye'den Örnekler)”, Gazi Beden Eğitimi ve Spor Bilimleri Dergisi (Gazi BESBD), 9(2), 69-76.

ŞENOL, Z. (2018). Spor Ekonomisinde Futbol Taraftarlarına Yönelik Kişilik ve Taraftarlık Analizi. Yüksek Lisans Tezi. Karabük: Karabük Üniversitesi Sosyal Bilimler Enstitüsü.

TALIMCİLER, A. (2008). “Futbol Değil İş: Endüstriyel Futbol”, İletişim Kuram ve Araştırma Dergisi, 26(Kış-Bahar), 89-114. 
https://evds2.tcmb.gov.tr/index.php?/evds/serieMarket/collapse_2/5868/DataGroup/tur kish/bie_rktufey/\#collapse. 02.07.2020

TCMB， (2020a). Reel Efektif Düviz https://www.tcmb.gov.tr/wps/wcm/connect/tr/tcmb+tr/main+menu/istatistikler/doviz+ kurlari/reel+efektif+doviz+kuruu. 04.08.2020

TCMB, (2020b). Reel Efektif Döviz Kuru Endeksleri’ne İlişkin Yöntemsel Açıklama. 8. https://www.tcmb.gov.tr/wps/wcm/connect/02713545-8428-49ab-a9d90f770895d513/REERMetaveri.pdf?MOD=AJPERES\&CACHEID=ROOTWORKSPA CE-02713545-8428-49ab-a9d9-0f770895d513-mBdDyxu. 05.08.2020

TERCI, M. G. (2019). "Futbol Kulüplerinin UEFA Finansal Fair Play Mali Kriterleri Kapsamında Denk Hesap Şartı ve Mali Yapılarının Rasyo Analizi Yöntemiyle İncelenmesi: Fenerbahçe A.Ş. Ve Trabzonspor A.Ş. Örneği”. Muhasebe ve Finans İncelemeleri Dergisi, 2(2), 81-93.

TFF, (2020). “TFF Statüler”. https://www.tff.org/default.aspx?pageID=133. 07.02.2020

TRANSFERMARKT, (2020). https://www.transfermarkt.com.tr/. 20.06.2020

TÜRKMEN, A. (2018). Türkiye İhracatında Ürün ve Ülke Çeşitlemesinin Sosyo-Ekonomik Belirleyicileri. Doktora Tezi. Erzurum: Atatürk Üniversitesi Sosyal Bilimler Enstitüsü.

TÜRKO, E. S. (2013). Endüstriyel Bölgelerde Dişsal Ekonomiler ve İş birliği Türkiye Ayakkabı Endüstrisinde Bir Uygulama. Doktora Tezi. Erzurum: Atatürk Üniversitesi Sosyal Bilimler Enstitüsü İktisat Anabilim Dalı.

UEFA, (2020). "Financial Fair Play”. https:/www.uefa.com/insideuefa/protecting-thegame/financial-fair-play/.

ULUYOL, U. (2014). “Süper Lig Futbol Kulüplerinin Finansal Performans Analizi”. Journal of Yasar University, 9(34), 5716-5731.

UTKULU, U. \& AYDEMİR, İ. (2013). Türkiye'de Dış Ticaret işlemleri ve Uygulaması. Ankara: Gazi Kitabevi.

ÜNSAL, E. M. (2017). Makro İktisat (Geliştirilmiş 11. Baskı). Ankara: Murat Yayınları.

WILLIAMS, J. \& NEATROUR, S. (2002). The 'New' Football Economics. http://www.le.ac.uk/footballresearch/resources/factsheets/fs10.html.

YİĞİT, E. (2018). Uluslararası Futbolcu Göçü ve Ekonomik Etkileri. Doktora Tezi. İstanbul: Marmara Üniversitesi Sosyal Bilimler Enstitüsü.

ZEREN, F. (2014). Futbol Kulüplerinin Sportif Başarılarının Hisse Senedi Fiyatlarına Etkisi. Doktora Tezi. Sakarya: Sakarya Üniversitesi, Sosyal Bilimler Enstitüsü. 